\title{
Policy opportunities and challenges from the COVID-19 pandemic for economies with large informal sectors
}

\section{Rajneesh Narula}

Henley Business School, University of Reading, Whiteknights, Reading, Berkshire RG6 6UD, UK

\section{Correspondence:}

R Narula, Henley Business School, University of Reading,

Whiteknights, Reading, Berkshire RG6 6UD, UK

e-mail: r.narula@henley.ac.uk

\begin{abstract}
In the developing world, the informal economy can account for as much as $80 \%$ of the population. I focus on the urban component of informality, where both informal employment and informal enterprises are especially vulnerable to the pandemic-induced economic shock. I explain the complex nature of informality, some of the reasons for its persistence and its interdependency with the formal economy, especially in the manufacturing sector, through global value chains (GVCs). Large firms (whether MNEs or domestic firms) subcontract considerable activity to informal enterprises, but this is precarious in character. I suggest the crisis provides the circumstances for greater active engagement with informal actors, by placing informal enterprises on a par with formal firms within industrial policy. I propose integration and registration, as opposed to formalisation, and the provision of state support without taxation. The role of the state is also crucial in matchmaking, creating incentives for GVCs to engage with informal actors systematically, and to reduce the transaction costs for informal actors in such engagement. These actions are likely to provide benefits in the longer run, even if they prove costly in the short run.
\end{abstract}

Journal of International Business Policy (2020) 3, 302-310. https://doi.org/ | 0. 1057/s422 | 4-020-00059-5

Keywords: global value chains; informal economy; COVID-19

\section{INTRODUCTION}

The most visible effect of the COVID-19 crisis in the developed world has been to the unemployed, the self-employed, casual and gig-workers, and small-scale entrepreneurs and businesses, which can be imperfectly described as those people and enterprises being in the informal sector. Informality is a universal feature of every economy, a term used to describe workers, activities and enterprises that are not (or weakly) monitored, regulated or registered by the government, and, by extension, have limited or no access to public support. The developed world tends to have low levels of informality, rarely more than a quarter of the population. These actors are fortunate that developed country governments have been able to extend emergency relief, in addition to a pre-existing safety net, however imperfect this safety net might be.
Received: 18 April 2020

Revised: 26 April 2020

Accepted: 27 April 2020

Online publication date: 25 June 2020 
In the developing world, informality is a much more pervasive phenomenon, with more than 2 billion people, representing $60 \%$ of workers and $80 \%$ of enterprises (ILO, 2020). The COVID-19 crisis is a stark reminder of the absence of any sort of social safety net. In this paper, I focus on the urban component of developing country informality (Lewis, 1954; Godfrey, 2011; Gollin, 2014; Narula, 2018, 2019) for three reasons. First, the rural economy tends to be overwhelmingly in subsistence agriculture, and less at risk economically from the crisis. Second, the urban poor account for at least half of the population in developing countries, and reside in high-density localities with precarious sanitary and health conditions. Third, the urban poor are disproportionally dependent on direct and indirect employment in the 'modern' economy (in the sense proposed by Lewis, 1954), ${ }^{1}$ mainly in manufacturing and service sectors. In the urban arena, international trade and investment often plays a significant role in commercial activity. The urban economy will be the most severely affected by the pandemic, because, even when the country in question has low levels of infection, both demand and supply of goods and services from abroad have been severely disrupted. Even where there has been low domestic mortality, this does not negate the possible economic shock. The more globally integrated the economy through supply chains, the more severe the economic implications of the pandemic (Sforza \& Steininger, 2020).

Developing country governments do not always have the resources to implement the basic WHO guidelines to counter the spread of COVID-19, although several have effectively tackled previous epidemics and pandemics. The scale and rapid spread of this pandemic may well overwhelm their public health infrastructure and its ability to trace, isolate or test infections. Physical distancing and large-scale lockdowns for extended periods are challenging where poverty levels are high and the urban populations are already close to (or below) the poverty line.

In this paper, I emphasise two aspects of informality: informal employment and informal enterprises. I also explain the complex nature of informality, some of the reasons for its persistence, and its interdependency with the formal economy, especially in the manufacturing sector, through global value chains (GVCs). Larger firms within supply chains (whether MNEs or domestic firms) often sub-contract considerable activity to informal enterprises, but this is precarious in character. I suggest the crisis may nonetheless generate the impetus for greater active engagement with informal actors. I propose that this should be done by placing informal enterprises on a par with formal firms within industrial policy. That is, I recommend integration and registration, as opposed to formalisation, and the provision of state support without taxation. The role of the state is also crucial in matchmaking, creating incentives for GVCs to engage with informal actors systematically, and to reduce the transaction costs for informal actors in such engagement. These actions are likely to provide benefits in the longer run, even if they prove costly in the shorter run.

\section{THE INFORMAL ECONOMY INTRODUCED}

Table 1 gives a good sense of the significance of the informal economy by region, and a selection of countries. The self-employed and micro-enterprises account for almost 70 per cent of employment in the Middle East and North Africa, and for more than 80 per cent in both South Asia and subSaharan Africa (ILO, 2019). India alone officially records 63 million micro-enterprises, employing 107 million people (Government of India, 2020). The unregistered enterprises, casual workers and subsistence traders likely account for a further 200300 million. Likewise, Africa has an estimated 300 million are in the informal sector (Jayaram, Leke, Ooko-Ombaka, \& Sun 2020).

Two types of informality are prevalent in an urban economy. The first is informal employment. This refers to workers employed by formal, registered firms on a casual, day-wage basis, as well as subsistence actors such as self-employed workers. This includes individuals and entrepreneurs that might undertake piecework in their own premises, street vendors and most domestic workers. They lack protection for non-payment of wages and retrenchment without notice, and often work under limited occupational safety conditions with no sick pay and health insurance.

The second group, and the focus of this paper, involves informal enterprises. They engage in coordinated commercial activity, such as bazaar traders, restaurants, and small ad hoc factories. They may or may not have a discernible organisational structure, with operations (and employment) that grows or shrinks, depending upon the demand for the enterprises' outputs or services. They are built around an actor/entrepreneur who engages in a 
Table 1 Informal employment in the non-manufacturing sector: selected countries and regions. Source: ILO (2018, Table B.2)

Share of informal employment as \% of non-agriculture employment (2016).

\begin{tabular}{ll}
\hline Africa & 71.9 \\
Nigeria & 89 \\
South Africa & 34 \\
Ghana & 82.6 \\
Uganda & 83.4 \\
Developing Americas & 49.6 \\
Brazil & 42.5 \\
Peru & 59.1 \\
Colombia & 55.4 \\
Mexico & 53.2 \\
Developing Asia-Pacific & 62.8 \\
Indonesia & 80.2 \\
Viet Nam & 57.9 \\
Pakistan & 70.8 \\
India & 78.1 \\
Bangladesh & 82 \\
Europe & 14.4 \\
Developed Americas & 18.9 \\
Developed Asia-Pacific & 19.5 \\
\hline
\end{tabular}

series of spot market transactions with customers, suppliers and workers, depending upon demand (Geertz, 1963). Informal enterprises are unable to seek (formal) credit, and have limited access to social programmes and public goods. Informal enterprises rarely invest in productivity-enhancing equipment, upgrade workers' skills, or achieve economies of scale, and tend to function on razor-thin margins. They have no recourse to legal protection should their customers renege on payment, and can offer no form of security to their employees, pay no taxes, and ignore minimum wage regulations. For instance, in Bangladesh, workers in the informal sector earn three times less than in formal firms (ILO, 2013).

The supply of low-skilled, low-cost labour in lessdeveloped economies is almost infinite, with considerable movement of surplus rural informal labour to urban locations, where employment in the urban informal sector provides opportunities less dependent on the vagaries of small-scale agriculture. When the economy is characterised by high unemployment, working below minimum wage is better than not working at all. Following the arguments of Lewis (1954), a near-inexhaustible supply of labour - in the absence of labour rights - keeps wage costs low, with workers as price-takers. Low-cost labour is thus a key comparative advantage for most developing countries.

This cost advantage through informality underlies much of the basis for participation in manufacturing value chains, especially in Asia. South Asia exports sports equipment, apparel and carpets, while agricultural products (from beef and wine to grain, tomatoes and coffee) play a significant role more evenly across much of the developing world, especially in Africa and Latin America. A majority of developing country exports are from these sectors, coordinated overwhelmingly by multinational enterprises (MNEs) through global value chains (GVCs). In less-developed economies and in agricultural GVCs, domestic actors tend to have a transactional relationship, selling 'raw' inputs to MNEs. In higher-income 'emerging' countries with manufacturing GVCs, there is a greater domestic engagement. GVCs are vertically de-integrated, relying on a variety of suppliers coordinated by the MNE affiliate. Formal suppliers (whether MNEs or domestic firms) tend to rely on informal employees, and sub-contract considerable activity to a network of informal enterprises. Neither public nor private regulators monitor this wide network of indirect suppliers and pieceworkers. The use of the informal sector is an important 'valve' for the formal firms (Narula, 2019). During periods of peak demand, informal enterprises take on tasks for which the formal firm has insufficient capacity, in addition to the formal firm drafting in extra casual workers as needed. Unfortunately, when demand is low, the reverse is the case - formal firms can act quickly to reduce costs by laying off informal employees and terminate purchasing from informal enterprises (or simply decline to pay, since they have no legal recourse).

It is uncontroversial that high levels of informality can limit human development. However, reducing informality significantly is no straightforward matter, requiring extended but gradual and sustained engagement with informal institutions that are deeply embedded in political, cultural and structural structures. Indeed, there is little clarity as to informality's causes, its persistence, or its remedy. What we do know is that a proliferation of informal activity in an economy reflects systemic failures, leading to weak institutions, endemic corruption, and large bureaucratic obstacles (and high entry barriers) to formal activity. Others point to political and regulatory capture by powerful interest groups, for whom a persistent supply of 
cheap (and unorganised) labour is an opportunity for rents (Estrin \& Mickiewicz, 2012). Political actors may have stakes in perpetuating the status quo. This is especially so in countries with weak political institutions, where inconsistency of policy and weak legal recourse is combined with political biases in favour of elites (Autio \& Fu 2015).

However, informality casts a long shadow. Even where institutions become more business friendly, actors may prefer to remain in the informal sector (Williams, Shahid, \& Martínez, 2016). A considerable literature has persuasively argued that informal actors are rational. They often choose to remain informal because there are viable economic reasons to do so. Even where economic and political institutions are stable and functional, the entrepreneur may possess an ownership advantage from being able to leverage complex networks across both sides of the economy, and therefore may perceive no economic benefit from formalisation. In other words, becoming formal may actually limit their capacity to generate rent. When the barriers to formalisation are high, this reinforces the tendency to remain informal. As implied by a variety of authors, in an environment of weak political and economic institutions, informality may well be a solution to poverty (De Soto, 2000; Godfrey, 2011; Estrin \& Mickiewicz, 2012; Autio \& Fu, 2015). From society's perspective, however, when entrepreneurs prefer to remain in the informal sector, this limits the funds available for public expenditures, leading to a vicious circle of increased taxation and fees on the formal firms, thereby reducing the competitiveness of formal firms, and encouraging further informality.

The charitable view is that the formal/informal interdependency reflects a pragmatic action by governments, or rather, a pragmatic inaction.

\section{COVID-19 AND THE LESS DEVELOPED COUNTRIES}

At the time of writing, a number of developing countries have chosen to initiate enforced physical distancing to limit the spread of the pandemic, although few governments are unable to offer significant support to incumbent formal actors, let alone informal actors. Already-high unemployment levels are likely to increase significantly. Stiglitz and Fitoussi (2019) do not exaggerate when they say that 'Anything unmeasured is invisible to policymakers'. Governments rarely have reliable data on the size and structure of their informal economy, ${ }^{2}$ and, to a large degree, they have mostly been ineffective in tackling informality even prior to the crisis. It is therefore unlikely that policymakers can reliably address the economic disruption to the informal sector. According to Jayaram et al. (2020), in the case of Africa, 35 million informal service sector jobs are vulnerable, as well as 15 million in the manufacturing and construction sectors. I consider this an under-estimation. The streamlining and shedding of direct employment by the non-agricultural sector is already happening in response to COVID-19. Private businesses, both foreign and domestic, will respond to the crisis by reducing their staff.

With so much of their populations in the informal sector, it is both logistically impossible and financially unmanageable to implement sophisticated 'rescue packages' for the vast numbers of small business owners/entrepreneurs and casual/subsistence workers, as have the developed countries (Joyce \& Xu, 2020). Lockdowns and physical distancing are impractical in densely populated slums and barrios. Residents literally live from hand to mouth. If they do not work, they do not eat, and this certainly means that they do not have money for rent, or such 'luxuries' as a hospital bed or medicines. Images from India during March/ April 2020 showed literally millions of informal workers trying to return to their ancestral villages, underscoring this point.

Even modest rescue packages will lead to a rise in both public and private debt. ECLAC (2020) estimates public debt levels across Latin America, already at $45 \%$ of GDP, will rise (despite debt forgiveness from lenders and donors and reduced interest rates). Prior to the crisis, IMF (2019a) noted that 34 of the 70 less-developed economies were at "high risk" of falling into debt distress or were already distressed, up from zero as recently as 2014 . The IMF also noted that many state-owned enterprises and private firms had taken advantage of cheap capital to significantly increase their debt over the last decade.

Shortfalls in revenues by both states and firms will require further borrowing, and greater dependence on aid. Countries dependent upon remittances as a key source of capital inflows are likely to experience a shock, as host countries ponder sending migrant workers back to their home countries (largely informally employed with limited labour rights, both in their host and home countries). The countries of the Gulf Cooperation Council host almost 20 million such workers. In Bangladesh, 
Pakistan and the Philippines, remittances rival FDI as a source of capital. In El Salvador and Honduras, remittances contributed around $20 \%$ of GDP in 2019.

Countries dependent on natural resource-intensive sectors have already suffered from declining prices over the last decade. ECLAC (2020) estimates for Latin America that the value of exports could fall by nearly $15 \%$, with an $8.8 \%$ drop in prices and a 6\% decline in volume. Nigeria's 2020 budget was planned against an oil price of $\$ 55$; it hovered around \$30 in May 2020. Collapse in demand from industrialised economies are not the only cause of revenue contraction: breakdowns in logistics and transport chains mean that agricultural exports will see a significant contraction (despite good harvests projected), as storage capacities for perishable goods are often poor in developing countries.

Even if the pandemic subsides, we cannot expect things to return to their pre-pandemic state even in the medium run. Although there is much talk about what policy actions less-developed countries can undertake to mitigate the economic costs of the pandemic (ESCAP, 2020; ECLAC, 2020), in reality, outside a handful of middle-income 'emerging' countries endowed with the appropriate infrastructure, few have the means to afford prudent and meaningful policy action. Some countries are taking steps to strengthen health systems and expand social safety nets, as well as to offer tax relief measures and credit guarantees, but meaningful action requires that there are efficient government agencies that can implement these measures.

Developing-country firms engaged in manufacturing GVCs are already experiencing an employment contraction, as they reduce employment of informal workers in line with depressed demand. The effect on informal enterprises is more ambiguous. On the one hand, few informal enterprises have the resources to remain in operation during a slowdown. On the other hand, since they tend to 'own' few physical assets, and employ people only on an intermittent basis, some are likely to reconstitute themselves once demand returns.

After the crisis, it is not obvious that manufacturing GVCs will return to the same reliance of formal-informal networks. Over the last decade, MNEs have been trying to reduce their dependence on informal enterprises, as NGOs, consumer groups and other stakeholders have continued to pressure them to take full chain responsibility, by reducing their dependence on suppliers with lower labour, health and safety standards (Narula, 2019). Major formal suppliers have been encouraged to involve fewer informal actors. COVID-19 will permit a further realignment. First, there may be a move to use suppliers in locations that are more expensive (but closer to key markets) through the substitution of capital for labour (Javorcik, 2020). Second, in the medium term, we will see a greater exclusion of the informal economy from productive activity by GVCs. Both will be to the detriment of countries seeking to leverage their low labour costs by engaging with manufacturing supply chains.

\section{A THIN SILVER LINING: USING THE CRISIS TO UPGRADE THE INFORMAL ECONOMY}

I see some benefits in this otherwise dismal crisis, because it highlights the precariousness of the informal sector and underscores the need to address informality. Industrial, investment and development policy that does not do so is necessarily incomplete. Why might governments address this more efficiently now? After all, the limits that informality places on growth have been well known for a few decades, nor have the system failures that have perpetuated informality suddenly disappeared, nor the government inefficiencies that discourage formality. Certainly, there are countries where political and social interest groups will act to maintain the status quo, and yet others where government inefficiencies verge on government failure. There are, nevertheless, developing countries whose policymakers recognise that a collapse of the informal sector removes the backbone of developing countries' economies. I believe that the pandemic is an exogenous shock of sufficient magnitude that it will motivate policymakers to realise that the long-term effects of not tackling informality now will be truly disastrous. Put more strongly, I believe that, if policymakers fail to act in the interests of such a significant majority of their populations, it will greatly exacerbate poverty levels due to the pandemic-related economic crisis.

Thus, I remain optimistic that there is a thin 'silver lining' to the crisis. The crisis has exposed significant market failures (e.g. allocative and productive inefficiencies, 'strategic' restrictions on exports) that represent new opportunities for entrepreneurs, and provide the circumstances for a modest infant industry industrialisation, by placing informal enterprises on a par with formal domestic firms. Note that I place emphasis on informal enterprises in this paper, largely because the nature of informal employment is much more 
complex and not yet well understood. Addressing informal employment more generally thus falls outside the scope of a single modest paper.

I do not make the case for new incentives to formalise informal enterprises; I am proposing acknowledging the informal economy and integrating it with the formal one. Formalisation has largely failed in the past, and there is no reason to expect that the current circumstances are that different. Informal entrepreneurs are also astute and riskaverse. Past government failures, policy reversals and inefficiencies live long in the public perception, and deter actors from formalising. In other words, even where there are good intentions, governments are distrusted due to prior inactions, entrenched regulatory capture or prior poor governance. Indeed, it is well established that economic actors crave stability of institutions and policy (Narula \& Dunning, 2010, Narula \& Pineli, 2019) and countries with high informality tend to have weak institutions and unstable political and regulatory track records.

Some states recognise their inability to address these structural and organisational challenges behind informality, and choose instead to accept the status quo. This is the passive and suboptimal option, and I propose that governments actively engage with informal actors as they do with formal enterprises. The informal sector is a crucial source of start-ups (Webb, Ireland, \& Ketchen, 2014). For the entrepreneur, trying out a business model is best done before incurring the costs of formalisation. This is especially so where the bureaucracy and cost of getting the necessary permissions is high.

I recommend including the informal sector in what are considered as 'horizontal actions' in industrial policy; programmes implemented on a universal basis across sectors. Changing perceptions about government ineptitude is as important as reducing the bureaucratic hurdles to formalise, but the latter requires systemic social changes. Integrating informal actors into existing schemes for formal firms is an incremental step, and relatively costless. It is easier to adapt state organs to recognise informal firms as an important aspect of their economies. Just as there are one-stop windows for foreign investors, there should be similar options for informal actors, along the classic lines of 'attraction, embedding and aftercare' (UNCTAD, 2007; Narula \& Dunning, 2010). To be clear, I propose integration and registration, as opposed to formalisation.
I am also proposing the provision of state support without taxation. States should actively champion informal enterprises, even though, unlike formal firms, there is likely little revenue benefit (but increased costs) to the state in the short and medium run. Most governments offer MNEs incentives to engage with formal enterprises within their supply chains; these should be extended to informal enterprises, which also tend to be micro-firms. Such enterprises (formal or informal) should be assisted - for instance, by providing training or by subsidising the certification of these firms - in the provision of higher workplace safety standards and better protection for workers. In other words, help the informal sector firms integrate in GVCs by providing the necessary transparency and accountability. This requires the active cooperation of lead firms and key suppliers. Given that MNEs are less constrained by existing network relationships, it is likely that foreign greenfield investors will prove more willing to do so than long-established foreign subsidiaries and domestic firms with well-developed local linkages.

This role of the state as impartial 'matchmaker' (Evans, 1995) is a critical one. Older, more established investors are normally reluctant to try new local suppliers and may have long-term relationships with foreign suppliers (Wade, 1990). We have seen cross-border value chains being disrupted as foreign inputs experience logistical and transportation delays, or because of export restrictions on these inputs. This is an opportunity for Investment Promotion Agencies (IPAs) to refine their 'aftercare' services, visiting larger MNE subsidiaries to identify (and resolve) bottlenecks in supply chains in the wake of COVID-19. It is often the case that foreign affiliates do not have sufficient knowledge of local capabilities, or have doubts about the quality and reliability of local alternatives. IPAs and governments can help reduce this search cost, and mitigate quality and price challenges for the local supplier through technical and financial assistance. At the very least, governments can act as guarantor for the local alternative, not only to prospective customers but also to financial institutions.

Deriving from this, there is an immediate shortterm opportunity from the COVID-19 pandemic. There is a window of opportunity for developing countries to encourage local actors to step in to fill the supply gap due to these market failures in international trade (even if it means subsidising the local supplier to meet the import prices). A simple example is the global shortage of personal 
protective equipment for hospitals (Bown, 2020). Hospitals, care homes and so forth are unable to purchase these goods as the global shortage has raised prices. Micro-firms and local entrepreneurs can produce hospital gowns and facemasks locally (with the government taking responsibility for sterilising and deep-cleaning the final product). Countries where there is a strong apparel and textile capacity have a key opportunity to retool their informal enterprises to meet new demand. Jayaram et al. (2020) reports that an apparel factory in Kenya shifted rapidly to mask production, and is already manufacturing 30,000 masks per day. Informal actors are already selling these masks on the streets of Lagos, Calcutta and Rio, but these entrepreneurs can be assisted to improve their products, hygiene and marketing, and to increase their productivity.

More generally, it is important to incentivise local firms/informal entrepreneurs to enter new markets. During the pandemic, and likely for some while after the pandemic, there will be greater demand for personalised assistance - in the form of tutors to educate children, delivery services, workers to take care of the elderly, and so on. Governments can offer, for instance, transportation to bring the unemployed graduates to rural and suburban areas where school-age children need assistance in their studies. In other instances, they might offer micro-firms assistance to advertise via social media, and to engage in e-commerce, by guaranteeing payment. This may simply require a method to provide quality assurance - that the tutor, helper or carpenter is indeed certified and qualified to provide services, and that their rates and quality of work is at the expected level.

These actions - reducing transaction costs for informal actors, and matchmaking - do not have to be expensive. The ubiquity of the smartphone in the developing world is an untapped benefit of the ICT revolution. There is no reason why 'paperwork' is still essential, nor the need to engage with unnecessary bureaucracy. Matchmaking, marketing, registration, permits, and so forth, can be done digitally, and the capabilities exist among local digital developers and entrepreneurs to provide these. Countries like Tanzania and Malawi have been fairly successful in doing so, despite limited resources (UNCTAD, 2020a, 2020b). The COVID-19 pandemic simply underscores this lost opportunity. As physical distancing and remote working may become a norm, here is a fresh (and urgent) opportunity to develop IT expertise. Pockets of
FinTech start-up firms in countries as diverse as Kenya, Nigeria and South Africa illustrate that the skills and the expertise are easily available locally, but governments have been unaccountably reluctant to draw upon them (IMF, 2019b).

\section{SOME CLOSING REMARKS}

FDI and trade have a complex relationship with economic development. I have conjectured elsewhere (Narula, 2018) that one of the reasons that there is so little evidence that MNEs have a significant positive influence on economic development is that spillovers and linkages are limited largely to the formal economy, as well as having a primarily urban footprint. The persistence of a large informal sector that is mired in low productivity, with limited absorptive capacity and poor access to public goods, and with few opportunities for social and economic growth, is a matter of great consternation to policymakers and development experts. The COVID-19 crisis has simply exacerbated the vulnerability of informal actors. I have not addressed the challenges of informal employment, nor indeed the challenges of informality in resource-dependent sectors, in countries such as South Africa. Peru, Bolivia and Ghana, where the informal/formal nexus is just as vexing and deeprooted. Informality, more broadly speaking, has historical, cultural and social causes, and can only be addressed through longer-term actions.

I am proposing that COVID-19 presents an opportunity for key horizontal actions to integrate informal enterprises into the commercial fabric of society. A number of governments have simplified the process of registration for formal firms, but these bureaucracies are often cumbersome, timeconsuming and expensive. This is the time not only to simplify but also to permit those entrepreneurs shy of formalisation, because of a fear of past bureaucratic excesses and inequities, a chance to avail of state support without expanded transaction costs. I extend this proposal for active integration to assisting informal enterprises to upgrade their capabilities to join GVCs and local supply chains, with governments facilitating this through digital market places, assistance with certifications, acting as guarantors, and providing (free) training in basic business skills to raise their productivity. Integration does not have to imply formalisation, but if these efforts to make their businesses more sustainable are successful, informal actors will likely 
choose to formalise if the benefits of doing so become obvious.

To address the precariousness of informal actors is to address the key bottleneck to growth. At the onset of the COVID-19 economic crisis, this is a crucial juncture to protect the most fragile of economic actors, regardless of their status.

\section{ACKNOWLEDGEMENTS}

Comments and feedback to an earlier version from Saul Estrin, Angela Garcia-Calvo, Mark Attah, James Walker, Khadija van der Straaten and Ari van Assche have helped immensely. All errors and misjudgements are strictly my own.

\section{NOTES}

${ }^{1}$ A key insight of the Nobel Laureate Arthur Lewis (1954) was that developing countries tend to have a dual structure: a 'traditional' sector, which is largely informal, and resource- and labour-intensive; and a 'modern' sector, which is more formal, and knowledge- and capital-intensive. Each part of this duality is associated with sectors and spatial locations, as there are different endowments of resources, reflecting a divide common in the post-industrial revolution era between the land economy (associated with rural areas and commodities) and the capital economy (associated with cities and human, technological and financial capital). Narula $(2015,2018)$ refines this argument to emphasise the further duality within the urban and rural economies, and explains why FDI may prove less beneficial in economies with a large informal sector.

${ }^{2}$ The absence of data means that solid economic studies from which to develop concrete recommendations are rare.

\section{REFERENCES}

Autio, E., \& Fu, K. 2015. Economic and political institutions and entry into formal and informal entrepreneurship. Asia Pacific Journal of Management, 32(1): 67-94.

Bown, C. 2020. Global supply chains will not be the same in the post-COVID-19 world. Chapter 2. In Baldwin, R. \& Evenett, S. (Eds.), Covid-19 and trade policy: Why turning inward won't work: 31-48. London: CEPR Press.

De Soto, H. 2000. Mystery of capital. New York: Basic Books.

ECLAC. 2020. Measuring the impact of COVID-19 with a view to reactivation. Special Report No 2.

ESCAP. 2020. The impact and policy responses for COVID-19 in Asia and the Pacific. https://www.unescap.org/sites/default/ files/COVID\%20_Report_ESCAP.pdf.

Estrin, S., \& Mickiewicz, T. 2012. Shadow economy and entrepreneurial entry. Review of Development Economics, 16(4): 559-578

Evans, P. 1995. Embedded autonomy: States and industrial. Transformation. Princeton: Princeton University Press.

Geertz, C. 1963. Peddlers and princes: Social development and economic change in two Indonesian towns. Chicago: University of Chicago Press.

Godfrey, P. C. 2011. Toward a theory of the informal economy. The Academy of Management Annals, 5(1): 231-277.

Gollin, D. 2014. The Lewis model: A 60-year retrospective. The lournal of Economic Perspectives, 28(3): 71-88.

Government of India. 2020. MSME Annual Report 2018-19, New Delhi.

ILO. 2013. Bangladesh: Seeking Better Employment Conditions for Better Socioeconomic Outcomes. Geneva: ILO.

ILO. 2018. Women and men in the informal economy: A statistical picture, 3rd ed. Geneva: ILO.

ILO. 2019. Small matters: Global evidence on the contribution to employment by the self-employed, micro-enterprises and SMEs. Geneva: ILO.

ILO. 2020. COVID-19 and the world of work: Updated estimates and analysis, ILO Monitor 2nd ed. Geneva: ILO.

IMF. 2019a. Global financial stability report: Lower for longer. Washington, DC, October.
IMF. 2019b. FinTech in Sub-Saharan African countries: A game changer? The African Department, 19/04, Washington, DC.

lavorcik, B. 2020. Global supply chains will not be the same in the post-COVID-19 world. Chapter 8. In Baldwin, R. \& Evenett, S. (Eds.), Covid-19 and trade policy: Why turning inward won't work: 111-116. London: CEPR Press.

layaram, K., Leke, A., Ooko-Ombaka, A., \& Sun, Y. S. 2020. Finding Africa's path: Shaping bold solutions to save lives and livelihoods in the COVID-19 crisis. McKinsey Institute, April 2020.

Joyce, R., \& Xu, X. 2020. Sector shutdowns during the coronavirus crisis: Which workers are most exposed? Institute for Fiscal Studies Briefing Note BN278.

Lewis, W. A. 1954. Economic development with unlimited supplies of labour. The Manchester School, 22(2): 139-191.

Narula, R. 2015. The viability of sustained growth by India's MNEs: India's dual economy and constraints from location assets. Management International Review, 55:191-205.

Narula, R. 2018. An extended dual economy model: Implications for emerging economies and their multinational firms. International Journal of Emerging Markets, 13(3): 586-602.

Narula, R. 2019. Enforcing higher labour standards within developing country value chains: Consequences for MNEs and informal actors in a dual economy. Journal of International Business Studies, 50(9): 1622-1635.

Narula, R., \& Dunning, J. H. 2010. Multinational enterprises, development and globalization: Some clarifications and a research agenda. Oxford Development Studies, 38(3):263-287.

Narula, R., \& Pineli, A. 2019. Improving the developmental impact of multinational enterprises: Policy and research challenges. Economia e Politica Industriale, 46: 1-24.

Sforza, A., \& Steininger, M. 2020. Globalization in the time of COVID-19 CESifo Working Paper No. 8184.

Stiglitz, J., Fitoussi, J. -P., \& Durand, M. 2019. Measuring what counts: The global movement for well-being. New York: The New Press.

UNCTAD. 2007. Aftercare: A core function in investment promotion. UNCTAD: Geneva. 
UNCTAD. 2020a. Malawi rapid eTrade readiness assessment, Geneva. Geneva: UNCTAD.

UNCTAD. 2020b. Tanzania rapid eTrade readiness assessment, Geneva. Geneva: UNCTAD.

Wade, R. 1990. Governing the market: Economic theory and the role of government in East Asian industrialization. Princeton: Princeton University Press.

Webb, J., Ireland, R., \& Ketchen Jr., D. 2014. Toward a greater understanding of entrepreneurship and strategy in the informal economy. Strategic Entrepreneurship Journal, 8(1): 1-15.

Williams, C. C., Shahid, M. S., \& Martínez, A. 2016. Determinants of the level of informality of informal micro-enterprises: Some evidence from the city of Lahore, Pakistan. World Development, 84: 312-325.

\section{ABOUT THE AUTHOR}

Rajneesh Narula is the John H. Dunning Chair of International Business Regulation at the Henley Business School, University of Reading. His research and consulting have focused on the role of multinational firms in economic development, innovation and industrial policy, informality, R\&D alliances and outsourcing.

Accepted by Ari Van Assche, Deputy Editor, 27 May 2020. This paper is part of a series of contributions dealing with the implications of the COVID-19 pandemic on international business policy, and it was single-blind reviewed.

Publisher's Note Springer Nature remains neutral with regard to jurisdictional claims in published maps and institutional affiliations. 